\title{
Kan Kültürlerinde İzole Edilerek Tanımlanan Mikroorganizmaların ve Antibiyotik Direnç Oranlarının Belirlenmesi
}

\author{
Halil ER*, Gülşah AŞIK**, Özlem YOLDAŞ**, Cengiz DEMİ***, Recep KEŞLİ** \\ *Mus Devlet Hastanesi, Mikrobiyoloji Laboratuvart \\ **Afyon Kocatepe Üniversitesi Tıp Fakültesi, Tıbbi Mikrobiyoloji Anabilim Dalı
}

\section{ÖZET}

\begin{abstract}
Amaç: Sepsis, mikroorganizmaların ve toksinlerinin kana karışımı sonucu gelişen, hayatı tehdit eden ve çok hızl ilerleyen klinik bir tablodur. Bu çalışmanın amacı, Afyon Kocatepe Üniversitesi Tıp Fakültesi Hastanesi'nde yatan hastalara ait kan kültürlerinden sepsis etkeni olarak izole edilen mikroorganizmaların tiplendirilmesi ve antibiyotik direnç oranları belirlenmesidir.
\end{abstract}

Gereç ve Yöntem: Kan kültürü örnekleri BACT/ALERT $3 D$ (BioMérieux, Marcy I'Etoile, Fransa) otomatize sistemi ile 5 gün inkübe edilmiştir. Mikroorganizmaların identifikasyonu konvansiyonel yöntemler ve BD Phoenix otomatize sistem (Becton Dickinson, Sparks, Maryland, ABD) ile yapılmıştır. Antibiyotik duyarlılıkları CLSI önerileri doğrultusunda Kirby-Bauer disk difüzyon yöntemi ile belirlenmiştir.

Bulgular: Çalışmaya dâhil edilen 4262 kan kültüiründen 765 (\%17.9)'i bakteriyemi ve sepsis etkeni olarak değerlendirilmiştir. İole edilen mikroorganizmalar arasında ilk sirayı Staphlococcus aureus (n:293, \%38.3) alırken, bunu koagülaz negatif Stafilokoklar (KNS) (n:139, \%18.2), Escherichia coli (n:93, \%12.1), Enterococcus spp. (n:56, \%7.3), Klebsiella pneumoniae (n:54, \%7.1), Acinetobacter baumannii (n:37, \%4.8), Pseudomonas aeruginosa (n:31, \%4.1), Brucella spp. (n:25, \%3.3), Candida spp. (n:25; \%3.3), Streptococcus pneumoniae (n:7; \%0.9) ve Serratia marcescens $(n: 5, \% 0.6)$ izlemiştir. S. aureus ve KNS üreyen örneklerde metisilin direnci sirast ile \%71.7 ve \%59.0 olarak tespit edilmistir. Enterokoklarda ise \%5.4 oraninda vankomisin direncine rastlanmıştır. Enterobacteriaceae türlerinde en yüksek oranda direnç seftazidime karşı görülürken, karbapenemlerin en etkili antibiyotik grubu olduğu belirlenmistir. Nonfermentetif bakterilerde ise aminoglikozidlerin en etkili antibiyotik grubu olduğu belirlenmiştir.

Sonuç: Kan kültürlerinden izole edilen mikroorganizmalar ve bunların antibiyotik duyarlllikları bölgelere ve hastanelere göre farklllık göstermektedir. Bu nedenle her hastanenin belli aralıklarla sepsis etkeni olan mikroorganizma dağılımı ve antibiyotik duyarlılıklarını raporlaması gerektiği düşünülmektedir.

Anahtar kelimeler: Antibiyotik duyarlılı̆̆g, kan kültürï, sepsis

\section{SUMMARY}

Determination of the Microorganisms Isolated from Blood Cultures and Their Antibiotic Susceptibility Rates

Aim: Sepsis is a serious, life-threatening condition that progresses very quickly due to the spread of microorganisms and their toxins in the blood. The aim of this study was to determine the distribution and antibiotic susceptibilities of the microorganisms isolated from blood cultures at Afyon Kocatepe University Medical Faculty Hospital, Turkey.

Materials and Methods: Blood culture samples were incubated in BACT/ALERT 3D automated system (Biomerieux, Marcy L'Etoile, France) for 5 days. Identification of the microorganisms was performed by conventional methods and the BD Phoenix automated system (Becton Dickinson, Sparks, Maryland, USA). Antibiotic susceptibilities were determined by the Kirby-Bauer disk diffusion method in accordance with CLSI recommendations.

Results: Among the 4262 blood cultures, 765 (17.9\%) revealed growth of microorganisms considered as causative agents of bacteremia and sepsis. The most frequently isolated microorganism was Staphylococcus aureus (n:293, 38.3\%) followed by coagulase negative staphylococci (CNS) $(n: 139,18.2 \%)$, Escherichia coli (n:93, 12.1\%), Enterococcus spp. (n:56, 7.3\%), Klebsiella pneumoniae (n:54,7.1\%), Acinetobacter baumannii (n:37, 4.8\%), Pseudomonas aeruginosa (n:31, 4.1\%), Brucella spp. (n:25, 3.3\%), Candida spp. $(n: 25,3.3 \%)$, Streptococcus pneumoniae $(n: 7,0.9 \%)$ and Serratia marcescens $(n: 5,0.6 \%)$. Methicillin resistance was determined in $71.7 \%$ of S. aureus and $59.0 \%$ of CNS strains. The rate of vancomycin resistance in enterococci was $5.4 \%$. The highest rates of resistance in Enterobacteriaceae were against ceftazidime. Carbapenems were determined to be the most effective antibiotic group against Enterobacteriaceae. Aminoglycosides were the most effective group of antibiotics in nonfermentative bacteria.

Conclusion: The distribution of the microorganisms isolated from blood cultures and their antibiotic susceptibility profiles vary in each hospital and geographical area. Thus, periodical report of antibiotic susceptibility profiles of blood pathogens is of crucial importance for the determination of empirical treatment protocols.

Key words: Antibiotic susceptibility, blood culture, sepsis

Alındığı tarih: 08.10.2015

Kabul tarihi: 12.11.2015

Yazışma adresleri: Halil Er, Muş Devlet Hastanesi, Mikrobiyoloji Laboratuvarı, Muş

e-posta: haliler004@hotmail.com 


\section{GíRiş}

Birçok enfeksiyon hastalığının seyri sırasında, travmatik ve cerrahi yaralar, yanıklar sonucunda bazı mikroorganizmalar kana karışarak bakteriyemilere ve septisemilere yol açabilmektedirler ${ }^{(1)}$. Kan dolaşımı enfeksiyonları kendini sınırlayan enfeksiyonla yaşamı tehdit eden sepsis, çoklu organ yetmezliği, yaygın damar içi pıhtılaşma gibi çeşitli klinik tablolara neden olabilir. $\mathrm{Bu}$ yüzden hızlı ve agresif antimikrobiyal tedaviye gereksinim duyulmaktadır ${ }^{(2)}$. Bakteriyemi ve sepsis, yüksek morbidite ve mortalite oranları ile seyreden, erken tanı konulup tedavi edilmesi gereken klinik tablolardır ${ }^{(3)}$. Kan kültürü, sepsis ve bakteriyemilere yol açan bu mikroorganizmaların izole edilerek tanımlanması amacıyla yaygın olarak kullanılmaktadır. Enfeksiyon etkenlerinin ortaya konulması ve antibiyotik duyarlılık testlerinin yapılarak doğru tedavinin yönlendirilmesinde ve mortalitenin azaltılmasında kan kültürü sonuçları büyük önem göstermektedir. Bakteriyemi ve sepsiste etken mikroorganizmaların dağılımları ve antibiyotik duyarlılıkları yıllara göre değişiklikler göstermektedir. Her hastane ampirik tedavide yol göstermesi açısından etken mikroorganizma ve antibiyotik duyarlılıklarında oluşan değişiklikleri yakından takip etmelidir ${ }^{(1,4)}$.

Amerika Birleşik Devletleri (ABD) verilerine göre, bakteriyemi ve septisemiden dolayı hastanede yatış oranı 10 yılda 326000'den 727000'e yükselmişti ${ }^{(5)}$. Bakteriyemi ve septisemiye neden olan mikroorganizmalar geniş bir dağılım göstermektedir. En sık gram pozitif koklar (özellikle stafilokoklar, streptokoklar ve enterokoklar) ile gram negatif basiller (özellikle Pseudomonas aeruginosa, Escherichia coli ve Klebsiella türleri) izole edilmektedir. Bakterilerin yanında Candida türleri başta olmak üzere mayalarda etken olarak tespit edilmektedir ${ }^{(6)}$.
Bu çalışmada, Afyon Kocatepe Üniversitesi Tıp Fakültesi Hastanesi'nde Eylül 2011-Ağustos 2013 tarihleri arası çeşitli klinikler ile yoğun bakım ünitelerinde yatan hastalara ait kan kültürlerinden izole edilen mikroorganizmaların tiplendirilmesi ve antibiyotik direnç oranlarının belirlenmesi amaçlanmıştır.

\section{GEREÇ ve YÖNTEM}

Afyon Kocatepe Üniversitesi Tıp Fakültesi Hastanesi'nde Eylül 2011 ile Ağustos 2013 tarihleri arasında yatan hastalardan alınan 4262 kan kültürü çalışmaya dâhil edilmiştir. Kan kültürü örnekleri BACT/ALERT 3D (BioMérieux, Marcy I'Etoile, Fransa) otomatize sistemi ile 5 gün inkübe edilmiştir. Brucella şüphesi olan örneklerin inkübasyonu 10 güne uzatılmıştır. Bu süre sonunda pozitif sinyal veren örneklerin $\% 5$ koyun kanlı agar, eozin metilen blue agar, çukulata agar ve sabaroud dekstroz agar besiyerlerine ekimleri yapılmıştır. Ekimleri yapılan besiyerleri, 24-48 saat $37^{\circ} \mathrm{C}$ 'de inkübe edilmiştir. Üreyen mikroorganizmaların identifikasyon ve antibiyotik duyarlılık çalışmaları konvansiyonel yöntemler ve Phoenix otomatize sistem (Becton Dickinson, Sparks, Maryland, ABD) ile yapilmıştır. Aynı hastadan aynı anda alınan kan örneklerinden yanlızca birinde cilt florasina ait olan Bacillus türleri, Corynebacterium türleri, mikrokoklar, Propniobacterium acnes ve koagülaz negatif Stafilokok ürerse bu kontaminasyon olarak değerlendirilmiştir. Üreme sonucu kontaminasyon olarak değerlendirilen örnekler çalışma dışı tutulmuştur. Antibiyotik duyarlılık çalışmaları Kirby-Bauer disk difüzyon metodu ile Mueller Hinton agar besiyeri kullanılarak yapılmış ve Clinical Laboratory Standards Insitute (CLSI) önerileri doğrultusunda değerlendiril$\operatorname{miştir}^{(7)}$. Stafilokok suşlarında metisilin direncinin tespitinde, disk difüzyon metodu ile sefoksi- 
tin ve oksasilin diskleri kullanılmış ve direçli bulunan suşlar metisilin dirençli olarak değerlendirilmiştir. Enterokoklarda vankomisin direnci ise disk difüzyon yöntemi ile saptanmış ve E-test (Liofilchem, Roseto degli Abruzzi, İtalya) yöntemi ile MIC değerleri tespit edilip doğrulama yapılmıştır.

\section{BULGULAR}

Çalışmaya dahil edilen 4262 kan kültüründen 765 (\%17.9)'i sepsis etkeni olarak değerlendirilmiştir. Bu izolatların identifikasyonları ve antibiyogram çalışmaları yapılmıştır. Üreme olan

Tablo 1. Kan kültürlerinden izole edilen mikroorganizmaların dağılım oranları.

\begin{tabular}{lrc}
\hline Mikroorganizmalar & n & \% \\
\hline Staphlococcus aureus & 293 & 38.3 \\
Koagülaz negatif Stafilokok & 139 & 18.2 \\
Escherichia coli & 93 & 12.1 \\
Enterococcus faecalis & 31 & 4.0 \\
Enterococcus faecium & 23 & 3.0 \\
Enterococcus gallinarum & 2 & 0.3 \\
Klebsiella pneumoniae & 54 & 7.1 \\
Acinetobacter baumannii & 37 & 4.8 \\
Pseudomonas aeruginosa & 31 & 4.1 \\
Brucella spp. & 25 & 3.3 \\
Candida spp. & 25 & 3.3 \\
Streptococcus pneumoniae & 7 & 0.9 \\
Serratia marcescens & 5 & 0.6 \\
\hline Toplam & 765 & 100.0 \\
\hline
\end{tabular}

örneklerden 495 (\%64.7)'i gram pozitif bakteri, 245 (\%32.0)'i gram negatif bakteri ve 25 (\%3.3)'i Candida türleri olarak tespit edilmiştir. Bütün bakteriler arasında S. aureus en sik etken (\%38.3) olarak tespit edilmiștir. Kan kültürlerinden izole edilerek tanımlanan mikroorganizmaların say1ları ve dağılım oranları Tablo 1'de verilmiştir.

Örnekler en çok dahili servislerden gelmiştir. Bunu yoğun bakımlar, pediatri servisleri ve cerrahi servisler izlemiştir. İzole edilen ve tanımlanan mikroorganizmaların servislere göre sayıları ve dağılım oranları Tablo 2'de verilmiştir.

Kültür sonucu gram pozitif üreme tespit edilen örneklerden $S$. aureus ve KNS üreyenlerde metisilin direnci (MRSA, MRKNS) sirasi ile $\% 71.7$ ve \%59.0 olarak tespit edilmiştir. Enterokoklarda ise, \%5.4 oranında vankomisin direncine rastlanmıştır. Vankomisine dirençli olarak tespit edilen 3 suşun biri Enterococcus faecium iken, 2 suş Enterococcus gallinarum olarak saptanmıştır. Tanımlanan gram pozitif bakterilerin test edilen antibiyotiklere karşı belirlenen direnç oranları Tablo 3 'te verilmiştir.

Tablo 2. İzole edilen mikroorganizmaların kliniklere göre dağılımları.

\begin{tabular}{|c|c|c|c|c|c|c|c|c|c|c|}
\hline & \multicolumn{2}{|c|}{ Cerrahi servisler } & \multicolumn{2}{|c|}{ Dahili servisler } & \multicolumn{2}{|c|}{ Pediatri servisi } & \multicolumn{2}{|c|}{ Yoğun bakım } & \multicolumn{2}{|c|}{ Toplam } \\
\hline & $\mathbf{n}$ & $\%$ & $\mathbf{n}$ & $\%$ & $\mathbf{n}$ & $\%$ & $\mathbf{n}$ & $\%$ & $\mathbf{n}$ & $\%$ \\
\hline Staphylococcus aureus & 49 & 6.4 & 118 & 15.4 & 69 & 9.0 & 57 & 7.5 & 293 & 38.3 \\
\hline KNS & 23 & 3.0 & 43 & 5.6 & 43 & 5.6 & 30 & 3.9 & 139 & 18.2 \\
\hline Escherichia coli & 14 & 1.8 & 46 & 6.0 & 10 & 1.3 & 23 & 3.0 & 93 & 12.1 \\
\hline Enterococcus spp. & 9 & 1.2 & 26 & 3.4 & 7 & 0.9 & 14 & 1.8 & 56 & 7.3 \\
\hline Klebsiella pneumoniae & 6 & 0.8 & 33 & 4.3 & 6 & 0.8 & 9 & 1.2 & 54 & 7.1 \\
\hline Acinetobacter baumannii & 11 & 1.4 & 5 & 0.7 & 1 & 0.1 & 20 & 2.6 & 37 & 4.8 \\
\hline Pseudomonas aeruginosa & 8 & 1.1 & 14 & 1.8 & 1 & 0.1 & 8 & 1.1 & 31 & 4.1 \\
\hline Brucella spp. & 1 & 0.1 & 20 & 2.6 & 4 & 0.5 & - & - & 25 & 3.3 \\
\hline Candida spp. & 8 & 1.1 & 10 & 1.3 & - & - & 7 & 0.9 & 25 & 3.3 \\
\hline Streptococcus pneumoniae & - & - & 5 & 0.7 & - & - & 2 & 0.2 & 7 & 0.9 \\
\hline Serratia marcescens & - & - & 5 & 0.7 & - & - & - & - & 5 & 0.6 \\
\hline Toplam & 129 & 16.9 & 325 & 42.5 & 141 & 18.4 & 170 & 22.2 & 765 & 100.0 \\
\hline
\end{tabular}


Tablo 3. Gram pozitif bakterilerde belirlenen antibiyotik direnç oranları.

\begin{tabular}{|c|c|c|c|c|c|c|c|c|c|c|}
\hline \multirow[b]{2}{*}{ Antibiyotikler } & \multicolumn{2}{|c|}{ KNS } & \multicolumn{2}{|c|}{ S. aureus } & \multicolumn{2}{|c|}{ E. faecalis } & \multicolumn{2}{|c|}{ E. faecium } & \multicolumn{2}{|c|}{ E. gallinarum } \\
\hline & n:139 & $\%$ & $\mathrm{n}: 293$ & $\%$ & $\mathrm{n}: 31$ & $\%$ & $\mathrm{n}: 23$ & $\%$ & $\mathrm{n}: 2$ & $\%$ \\
\hline Penisilin & 133 & 95.6 & 230 & 78.5 & 19 & 62.5 & 15 & 65.2 & 1 & 50.0 \\
\hline Eritromisin & - & - & - & - & 27 & 83.7 & 19 & 82.6 & 1 & 50.0 \\
\hline Sefoksitin & 82 & 59.0 & 210 & 71.7 & - & - & - & - & - & - \\
\hline Gentamisin-sinerji & - & - & - & - & 23 & 74.2 & 19 & 82.6 & 1 & 50.0 \\
\hline Vankomisin & 0 & 0.0 & 0 & 0.0 & 0 & 0.0 & 1 & 4.3 & 2 & 100.0 \\
\hline Teikoplanin & 0 & 0.0 & 0 & 0.0 & 0 & 0.0 & 1 & 4.3 & 0 & 0.0 \\
\hline Sefepim & 85 & 61.2 & 259 & 88.4 & - & - & - & - & - & - \\
\hline Ampisilin & - & - & - & - & 10 & 32.2 & 18 & 78.3 & 1 & 50.0 \\
\hline Ampisilin sulbaktam & 121 & 87.1 & 214 & 73.0 & - & - & - & - & - & - \\
\hline Sefotaksim & 117 & 84.2 & 215 & 73.4 & - & - & - & - & - & - \\
\hline Linezolid & 0 & 0.0 & 0 & 0.0 & 0 & 0.0 & 0 & 0.0 & 0 & 0.0 \\
\hline
\end{tabular}

* Test edilmeyen antibiyotik

Tablo 4. Gram negatif bakterilerde belirlenen antibiyotik direnç oranları.

\begin{tabular}{|c|c|c|c|c|c|c|c|c|}
\hline \multirow[b]{2}{*}{ Antibiyotikler } & \multicolumn{2}{|c|}{ KNS } & \multicolumn{2}{|c|}{ K. pneumoniae } & \multicolumn{2}{|c|}{ A. baumannii } & \multicolumn{2}{|c|}{ P. aeruginosa } \\
\hline & n:93 & $\%$ & $\mathrm{n}: 54$ & $\%$ & n:37 & $\%$ & n:31 & $\%$ \\
\hline Amikasin & 4 & 4.3 & 4 & 21.6 & 17 & 45.9 & 0 & 0.0 \\
\hline Gentamisin & 43 & 46.2 & 21 & 38.9 & 19 & 51.3 & 4 & 12.9 \\
\hline Sefepim & 40 & 43.0 & 19 & 35.2 & 34 & 91.9 & 17 & 54.8 \\
\hline Seftazidim & 72 & 77.4 & 34 & 63.0 & 35 & 94.6 & 28 & 90.3 \\
\hline Seftriakson & 55 & 59.1 & 24 & 44.4 & - & - & - & - \\
\hline Sefeperazon sulbaktam & 18 & 19.4 & 20 & 37.0 & 33 & 89.2 & 30 & 96.8 \\
\hline Piperasilin tazobaktam & 10 & 10.7 & 10 & 18.5 & 35 & 94.6 & 27 & 87.1 \\
\hline Siprofloksasin & 59 & 63.4 & 23 & 42.6 & 34 & 91.9 & 10 & 32.2 \\
\hline Levofloksasin & 53 & 57.0 & 20 & 37.0 & 35 & 94.6 & 15 & 48.4 \\
\hline İmipenem & 1 & 1.1 & 2 & 3.7 & 34 & 91.9 & 13 & 41.9 \\
\hline Meropenem & 1 & 1.1 & 2 & 3.7 & 34 & 91.9 & 10 & 32.2 \\
\hline Trimetoprim-sulfametaksazol & 44 & 47.3 & 15 & 27.8 & 25 & 67.6 & 31 & 100.0 \\
\hline
\end{tabular}

* Test edilmeyen antibiyotik

Enterobacteriaceae türlerinde en yüksek oranda direnç seftazidime karşı görülürken, karbapenemlerin en etkili antibiyotik grubu olduğu belirlenmiştir. Non fermentatif bakterilerde ise, aminoglikozidlerin en etkili antibiyotik grubu olduğu belirlenmiştir. Gram negatif bakterilerin test edilen antibiyotiklere karş1 belirlenen direnç oranları Tablo 4'te verilmiştir.

\section{TARTIŞMA}

Bakteriyemi ve sepsis, yüksek mortalite ve morbiditeyle seyreden, erken tanı konulup tedavi edildiğinde mortalite oranlarının önemli ölçüde azaldığ antibiyotiklerin kullanıma girmesi, hasta popülasyonundaki değişiklikler, immunsupresyon, altta yatan hastalıklardaki artış, kateter ve intravenoz solüsyonların daha sık kullanılması gibi nedenlerle, son yıllarda mikroorganizmaların kandan izole edilme oranlarında artış olmuş$\operatorname{tur}^{(8)}$.

Bakteriyemiye neden olan mikroorganizmaların dağılımında, zaman içinde değişiklikler gözlenmiştir. Hastanelerde endemik olarak bulunan mikroorganizmalar ve bunların antibiyotiklere duyarlılıklarının değişmesi bu değişikliklerin en önemli nedenlerindendir ${ }^{(9)}$. 
Bakteriyemi etkenleri ile ilgili önceki yıllarda yapılan çalışmalar incelendiğinde, 1960-1970 yılları arasında gram negetif etkenler ilk sirayı alırken, 1980'li yıllardan sonra gram pozitif etkenler ilk sıraya yerleşmeye başlamıştır ${ }^{(10)}$. Ülkemizde yapılan çalışmalarda, gram pozitif etkenler ve gram negatif etkenlerin sıklığını sıras1 ile Öksüz ve ark. ${ }^{(1)}, \% 64.1$ ve $\% 35.6$, Ece $^{(12)}$ $\% 71.1$ ve $\% 27.8$, Yüce ve ark. ${ }^{(13)} \% 28.1$ ve $\% 59.8$, Duman ve ark. ${ }^{(14)} \% 68.5$ ve $\% 31.5$, Y1lmaz ve ark. ${ }^{(15)} \% 31.1$ ve $\% 61.0$ olarak bildirmişlerdir. Çalışmamızda ise 495 (\%64.7) gram pozitif, 245 (\%32.0) gram negatif ve 5 (\%0.6) Candida türlerinin üremesi tespit edilmiştir. Çalışmamızdan elde ettiğimiz sonuçların ülke genelindeki farklı merkezlerde yapılan bazı çalışma sonuçları ile uyumlu olduğu görülmektedir. Yapılan çalışmalar arasında bu şekilde farklılıkların bulunması, hastanelerin floralarının farklılı̆̆ını, hastaneye yatan hasta profillerinin ve uygulanan antibiyotik tedavilerinin farklılık göstermesinden kaynaklandığı düşündürmektedir.

Kan kültürlerinden izole edilen gram pozitif bakterilerin çoğu S. aureus ve KNS'lerden oluşmaktadır. Ülkemizde yapılan çalışmalarda S. aureus ve KNS saptanma oranlarını sırası ile Öksüz ve ark. $^{(11)} \% 25.0$ ve $\% 34.0$, Ece $^{(12)} \% 2.7$ ve $\% 64.7$, Yüce ve ark. ${ }^{(13)} \% 13.9$ ve $\% 9.2$, Duman ve ark..$^{(14)}$ $\% 4.8$ ve $\% 49.6$, Yilmaz ve ark. ${ }^{(15)} \% 8.5$ ve $\% 13.3$, Demirbakan ve ark. ${ }^{(16)} \% 14.7$ ve $\% 25.9$ olarak bildirmişlerdir. Bu sonuçları, diğer çalışmalardan elde edilen sonuçlar ile karşılaştırdığımizda $S$. aureus etken olarak izole edilme oranının diğer çalışmalardan daha yüksek, KNS izolasyon oranlarının ise iki çalışmadan (Yüce ve ark. ${ }^{(13)}$, Yılmaz ve ark. ${ }^{(15)}$ ) yüksek, diğer çalışmalardan elde edilen oranlardan daha düşük olduğu görülmektedir. Çalışmamızda, S. aureus'ların etken olarak saptanma oranının daha yüksek olması hastanelerin floralarının farklı olmasın- dan kaynaklandığı düşündürtmektedir.KNS'lerin yüksek oranda bulunmasinda hastanede yatan hastalarda girişimsel işlemlerin sıklıkla uygulanması ve intravasküler katater takılması gibi nedenlere bağlı olduğu düşünülmektedir.

Metisilin dirençli stafilokoklar bakteriyemilerde mortalite, morbiditenin ve tedavi maliyetlerinin artmasina neden olmaktadir. S. aureus ve KNS'lerde metisilin direncini Yüce ve ark. ${ }^{(13)}$ $\% 69.5$ ve $\% 56.4$, Duman ve ark. ${ }^{(14)} \% 30.8$ ve \%64.4, Y1lmaz ve ark. ${ }^{(15)} \% 28.4$ ve \%89.7, Demirbakan ve ark. ${ }^{(16)} \% 42.0$ ve $\% 63.0$ olarak tespit etmişlerdir. Çalışmamızda, bu oranları $\% 71.7$ ve \%59.0 olarak bulunmuştur. Metisilin direnci açısından çalışmamızda elde edilen oranları diğer çalışmalar ile karşılaştırdığımızda, S. aureus'lar için, bir çalışma ile uyumlu (Yüce ve ark. ${ }^{(13)}$ ), diğer çalışmalardan yüksek olduğu, KNS'ler için ise bir çalışmadan düşük, ancak diğer çalışmaların tamamı ile uyumlu olduğu görülmektedir. Bu durum hastanelerde kullanılan antibiyotik profillerinin farklılık göstermesi ve yatan hastaların çeşitliliği sonucu hastane florasında oluşan değişikliklerle açıklanabilir.

Ülkemizde yapılan çalışmalarda, enterokoklarda vankomisin direnç oranını Duman ve ark. ${ }^{(14)}$ $\% 1.5$, Y1lmaz ve ark. ${ }^{(15)} \% 1.39$ olarak tespit ederken, Demirbakan ve ark. ${ }^{(16)}$, Öksüz ve ark..$^{(11)}$ ve Ece ${ }^{(12)}$ vankomisin direnci tespit etmemiştir. Çalışmamızda, bu oran \%5.4 ile, diğer çalışmalardan yüksek olarak bulunmuştur. Hastane enfeksiyonu açısından son derece önemli olan bu izolatların sıkı takibi ve hastaneden eredike edilmesi önemlidir. Vankomisine dirençli enterokok tespit edilen hastaların temas izolasyonlar1 yapılarak diğer hastaları enfekte etmelerinin önüne geçilmelidir. 
E. coli ve K. pneumoniae türlerine karşı Öksüz ve ark. ${ }^{(11)}$ imipenem ve amikasini en etkili antibiyotik olarak tespit ederlerken, trimetoprimsulfametaksazolü ise en dirençli antibiyotik olarak bulmuşlardır. Duman ve ark. ${ }^{(14)}$ yaptıkları çalışmada imipenem, meropenem ve amikasine direnç tespit etmezken, en dirençli antibiyotik olarak amoksisilin klavulanik asit ve sefuroksim aksetili bildirmişlerdir. Yılmaz ve ark. ${ }^{(15)}$, en duyarlı antibiyotik olarak amikasin, imipenem ve meropenemi, en dirençli antibiyotik olarak da trimetoprim-sulfametaksazol ve siprofloksasini saptamışlardır. Çalışmamızda da benzer şekilde imipenem, meropenem ve amikasine düşük oranlarda direnç tespit edilirken, sefalosporin ve kinolon grubu antibiyotiklere yükssek direnç bulunmuştur. Çalışmalar arasında farklı oranların bulunması, tamamen ilgili çalışmaların yapıldı ğı merkeze ait olan özelliklerden kaynaklanmaktadır ve bu açıdan farklı oranların bulunması normal olarak yorumlanabilir.

$P$. aureginosa ve $A$. baumannii türlerinde ise Demirbakan ve ark. ${ }^{(16)}$ imipenem, meropenem ve sefoperazon-sulbaktamı en duyarlı, sefotaksim, sefoperazon ve aztreonam en dirençli antibiyotikler olarak bildirilmiştir. Çalışmamızda aminoglikozit grubu antibiyotikler en duyarlı antibiyotik grubu olarak bulunmuştur. Bu dirençteki farklılıklar, ampirik olarak hastalara başlanan antibiyotik gruplarının hastaneler arası farklı olması ve bu sık kullanılan antibiyotik gruplarından dolayı yaygın direnç gelişimi ile açıklanabilir.

Kan kültürlerinden izole edilen bakterilerin çeşitliliği ve antibiyotiklere olan duyarlılıkları, coğrafik bölgelere, hastane florasına, hastanede kullanılan antibiyotiklere ve hastaneye yatan hasta profillerine göre değişiklik göstermektedir.
Bu nedenle her hastanenin belli aralıklarla kendi bakteri dağılımı ve antibiyotik duyarlılıklarını çıkarıp bu sonuçlara göre tedavi protokolleri oluşturması gerekmektedir. Bu sonuçların özellikle klinisyenin ampirik tedavi protokollerinde yol gösterici olacağı kanaatindeyiz.

\section{KAYNAKLAR}

1. Köksal F, Samastı M. Kan kültüründen izole edilen stafilokoklarda antibiyotik direnci. ANKEM Derg 2002;16:10-3.

2. Negussie A, Mulugeta G, Bedru A, Ali I, Shimeles D, Lema T,Aseffa A. Bacteriological profile and antimicrobial susceptibility pattern of blood culture isolates among septicemia suspected children in selected hospitals Addis Ababa, Ethiopia. Int J Biol Med Res 2015; 6:4709-17.

3. Weinstein MP. Current blood culture methods and systems: clinical concepts, technology, and interpretation of results. Clin Infect Dis 1996; 23:40-6. http://dx.doi.org/10.1093/clinids/23.1.40

4. Gül Yurtsever S, Baran N, Afşar i, Yalçın MA, Kurultay N, Türker M. İzmir Atatürk Eğitim ve Araştırma Hastanesi'nde kan kültürlerinden izole edilen mikroorganizmalar ve antibiyotiklere karşı duyarl1lıklar1. Klimik Derg 2006; 19:56-9.

5. Hall MJ, Williams SN, DeFrances CJ, Golosinskiy A. Inpatient care for septicemia or sepsis: A challenge for patients and hospitals. NCHS Data Brief 2011; 62:1-8.

6. Khaleel ME, Lone DS, Munir M, Khan JK, Zahra KT, Hanif A. A Study of Microbial Isolates from Blood at a University Teaching Hospital. Annals of King Edward Medical University 2010; 16:194-7.

7. Clinical and Laboratory Standards Institute: Performance Standards for Antimicrobial Susceptibility Testing, Twentieth Informational Supplement, M100S20, CLSI, Wayne, PA, 2010.

8. Doğanay M, Meşe EA. Sepsis. Willke Topçu A, Söyletir G, Doğanay M. Enfeksiyon Hastalıkları ve Mikrobiyolojisi. Nobel Tip Kitabevleri, İstanbul, 2008: 877-97.

9. Sümerkan B. Nozokomiyal sepsis. Etiyoloji ve mikrobiyolojik tanı. Hastane Enfeksiyon Derg 1998; 2:182-7.

10. Kim HJ, Lee NY, Kim S, et al. Characteristics of microorganisms isolated from blood cultures at nine university hospitals in Korea during 2009. Korean J Clin Microbiol 2011; 14:48-54.

http://dx.doi.org/10.5145/KJCM.2011.14.2.48

11. Öksüz Ş, Yavuz T, İdris Ş, Yıldırım M, Akgünoğlu M, Kaya D, Öztürk E. Kan kültürlerinden izole edilen mikroorganizmalar ve antibiyotiklere duyarlılıkları. 
Turk Mikrobiyol Cem Derg 2008; 38:117-21.

12. Ece G. Kan kültüründe üreyen izolatların dağılımı ve antibiyotik duyarlılık profilinin incelenmesi. Haseki Tıp Bülteni 2013; 51:151-6.

http://dx .doi.org/10.4274/Haseki.1044

13. Yüce P, Demirdağ K, Kalkan A, Özden M, Denk A, Kılıç SS. Kan kültürlerinde izole edilen mikroorganizmalar ve antibiyotik duyarlılıkları. ANKEM Derg 2005; 19:17-21.

14. Duman Y, Kuzucu Ç, Çuğlan SS. Kan kültürlerinden izole edilen bakteriler ve antimikrobiyal duyarlılıkları. Erciyes Tip Dergisi 2011; 33:189-96.

15. Yılmaz S, Gümral R, Güney $M$ ve ark. İki yıllık dönemde kan kültürlerinden izole edilen mikroorganizmalar ve antibiyotik duyarlılıkların değerlendirilmesi. Gülhane Tıp Dergisi 2013; 55:247-52.

16. Demirbakan H, Dağlar D, Yıldırım Ç ve ark. Kan kültürlerinden izole edilen bakteriler ve antibiyotiklere duyarlılıkları. Turk Mikrobiyol Cem Derg 2005; 35:183-8. 